\section{Bacterial Desulfonation of the Ethanesulfonate Metabolite of the Chloroacetanilide Herbicide Metazachlor}

HEIKE LAUE, ${ }^{+}$

JENNIFER A. FIELD, $\neq A N D$

ALASDAIR M. COOK*,†

Fakultät für Biologie, Universität Konstanz,

D-78434 Konstanz, Germany, and Department of Agricultural

Chemistry, Oregon State University, Corvallis, Oregon 97331

M etazachlor $\left(\mathrm{R}-\mathrm{CH}_{2}-\mathrm{Cl}\right)$, a chloroacetanilide herbicide, is converted in soil to products including the ethanesulfonate metabolite ( $\mathrm{R}-\mathrm{CH}_{2}-\mathrm{SO}_{3}{ }^{-} ; \mathrm{BH}$ 479-8). Nothing is known about the degradation of the ethanesulfonates of this class of herbicides. We used inocula derived from five sources for enrichment cultures to utilize $\mathrm{R}-\mathrm{CH}_{2}-\mathrm{SO}_{3}{ }^{-}$as a sole sulfur source for the grow th of microorganisms. Each culture yielded bacteria that caused the disappearance of $\mathrm{R}-\mathrm{CH}_{2-}$ $\mathrm{SO}_{3}{ }^{-}$and the formation of a product identified as the glycolate metabolite $\left(\mathrm{R}-\mathrm{CH}_{2}-\mathrm{OH} ; \mathrm{BH} 479-1\right)$ by mass spectrometry. A pure culture, strain HL1, was isolated, and this bacterium quantitatively desulfonated $\mathrm{R}-\mathrm{CH}_{2}-\mathrm{SO}_{3}{ }^{-}$, the sulfur being recovered in cell protein. Recovery of the organic moiety was usually about $80 \%$. A second ethanesulfonate $\left(\mathrm{R}^{\prime}-\mathrm{CH}_{2}-\mathrm{SO}_{3}{ }^{-}\right)$and two alkylsulfonates, but not taurine, were utilized by strain HL1 as sulfur sources.

\section{Introduction}

A major fate of chloroacetanilide herbicides in soil is attack by glutathione transferases (Figure 1) (1-3). The glutathione conjugate is then subject to further biotransformation, which leads to the formation of, for example, the "ethanesulfonate" metabolite (2-4), whose formation from alachlor (4), propachlor (2), acetochlor (3), and metazachlor (5) (Figure 1) has been detected. The ethanesulfonate metabolite seems to be stable in the soils studied (6).

It was of interest to explore whether the compound is likely to be stable in all environments or if it is susceptible to any form of microbial attack. A routine approach to this question is to deviate from the standard, carbon-limited growth medium and to ask whether other moieties in the molecule are availableto microorganisms $(7,8)$. Thesulfur moiety in xenobiotics, especially the sulfonate moiety, has been found to be readily removable as a sulfur source for

* Correspondingauthor telephone: ++497531884247 ; fax: ++49 753188 2966; e-mail address: Alasdair.Cook@uni-konstanz.de.

† Universität Konstanz.

‡ Oregon State University. growth $(9,10)$. We now observe that enrichment cultures to desulfonate the ethanesulfonate metabolite of metazachlor $\left(\mathrm{R}-\mathrm{CH}_{2}-\mathrm{SO}_{3}{ }^{-}\right)$are readily obtained and that a defined desulfonation product is obtained.

\section{Experimental Section}

Materialsand Apparatus. Metazachlor [N-(2,6-dimethoxyphenyl)-N-(pyrazol-1-ylmethyl)chloroacetanilide; BAS479 $\mathrm{H}$; $\mathrm{R}-\mathrm{CH}_{2}-\mathrm{Cl}$ is the parent compound from which the ethanesulfonatemetabolite R- $\mathrm{CH}_{2}-\mathrm{SO}_{3}{ }^{-}$is derived. $\mathrm{R}-\mathrm{CH}_{2-}$ $\mathrm{SO}_{3}{ }^{-}$(BH 479-8; >99\%) was kindly provided by BASF AG (Ludwigshafen, Germany), which al so supplied the glycolic acid ( $\mathrm{R}-\mathrm{CH}_{2}-\mathrm{OH}$; $\mathrm{BH} 479-1 ;>99 \%$ ) and the oxalic acid (R$\mathrm{COOH}$; $\mathrm{BH} 479-4 ; 99 \%)$ derivatives (Figure 1). Whereas $\mathrm{R}-\mathrm{CH}_{2}-\mathrm{OH}$ chromatographed as a single peak, $\mathrm{R}-\mathrm{CH}_{2}-\mathrm{SO}_{3}-$ and $\mathrm{R}-\mathrm{COOH}$ each chromatographed as pairs of peaks due to the hindered rotation of the acid group and theexistence of rotamers. Theethanesulfonatederivative $\left[\mathrm{R}^{\prime}-\mathrm{CH}_{2}-\mathrm{SO}_{3}{ }^{-}\right.$; 99\% (Figure 1)] of a plant safener [1-(2,2-dichloroacetyl)3,3,8-trimethylperhydropyrolo[1,2- $\alpha$ ]pyrimidin-5-one; R'$\mathrm{CHCl}_{2}$ ] was also supplied by BASF. Analytical grade chemicals were used throughout the work. Plate Count Agar was from Difco and MacConkey Agar No. 3 was from Oxoid. The test kitsfor L-alaninepeptidase and the oxidase test were from Merck. Horse liver alcohol dehydrogenase (Boehringer) and $\mathrm{NAD}^{+}$(Merck) were from commercial sources. HPLC was done with Beckman apparatus equipped with a diode array detector. Ion chromatography with suppression was done with a Sykam apparatus. A Finnigan Model 4023mass spectrometer was used for direct probe analyses.

Analytical Methods. Reversed-phase HPLC was done with Nucleosil 5-C18 as the stationary phase in $125 \times 3 \mathrm{~mm}$ columns. The mobile phase was $40 \%$ (20\%) methanol and $60 \%$ (80\%) $10 \mathrm{mM}$ potassium phosphate buffer, $\mathrm{pH} 2.2$, at a flow rate of $0.5 \mathrm{~mL} / \mathrm{min}$ for the herbicide derivatives (safener derivatives). Bacterial cultures were centrifuged (18000g, $2 \mathrm{~min}$, room temperature) and filtered $(0.45 \mu \mathrm{m}$ pore diameter) prior to analysis by HPLC, where $100-\mu \mathrm{L}$ portions were injected onto the column. Occasionally, spent medium was concentrated 10-fold under a stream of nitrogen, and putative $\mathrm{R}-\mathrm{CH}_{2}-\mathrm{OH}$ from $500-\mu \mathrm{L}$ portions was collected after separation on the HPLC column. The mass spectrometer was operated in chemical ionization mode with methane as the reagent gas to examine the authentic $\mathrm{R}-\mathrm{CH}_{2}-\mathrm{OH}$ standard and putative $\mathrm{R}-\mathrm{CH}_{2}-\mathrm{OH}$, which had been separated by HPLC. Thesourcetemperaturewas 120 ${ }^{\circ} \mathrm{C}$, and the electron energy was $70 \mathrm{eV}$. Sulfate ion in the growth medium was determined by ion chromatography on an LCA A01 anion-exchanger column with $3 \mathrm{mM}$ $\mathrm{NaHCO}_{3}$ plus $2 \mathrm{mM} \mathrm{Na} \mathrm{CO}_{3}$ containing $0.5 \%$ butanol as the mobile phase, according to the manufacturer's instructions (Sykam). Protein in bacterial cultures was measured by a Lowry method (11).

Enrichment Cultures and Growth Conditions. The enrichment cultures were prepared to select for the utilization of the sulfur in $\mathrm{R}-\mathrm{CH}_{2}-\mathrm{SO}_{3}{ }^{-}$at $30^{\circ} \mathrm{C}$. The inocula were from five independent sources: forest soil; soil from an oat field; and from sewage sludges from rural (Trogen), largely communal (Werdhölzli), and largely industrial (Herisau) treatment plants (cf. ref 12). Inocula were 


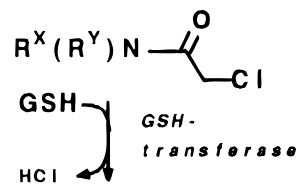

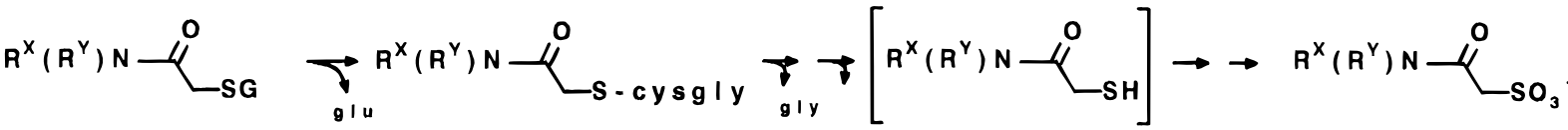

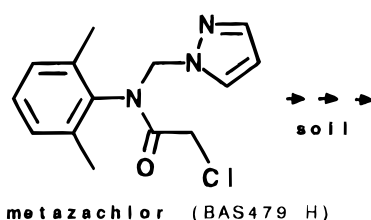

metazachlor
$\left(\mathrm{C}-\mathrm{CH}_{2}-\mathrm{CI}\right)$

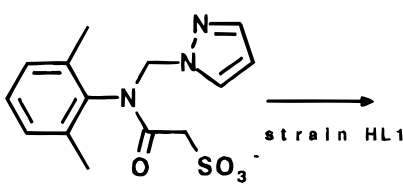

(BH $479 \cdot 8)$

$\mathrm{R} \cdot \mathrm{CH}_{2} \cdot \mathrm{SO}_{3}$

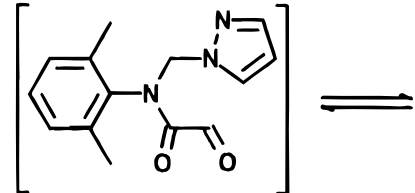

A. CHO

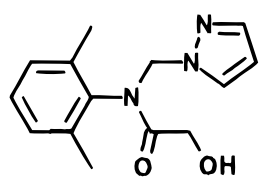

$(\mathrm{BH} 479.1)$ A. $\mathrm{CH}_{2}-\mathrm{OH}$

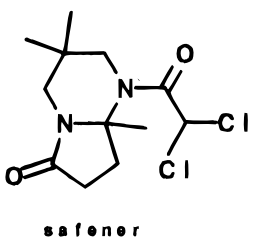

( A $^{-}-\mathrm{CHCl}_{2}$ )

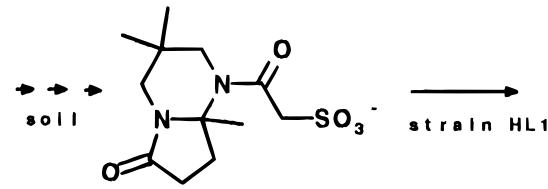

' $\cdot \mathrm{CH}_{2}-\mathrm{SO}_{3}$

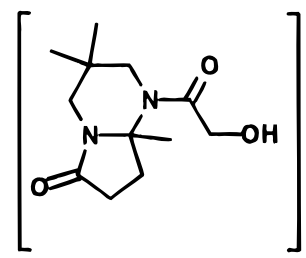

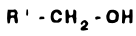

FIGURE 1. Generalized scheme of dechlorination of a chloroacetanilide herbicide by a glutathione (GSH, $\gamma$-L-glutamyl-L-cysteinylglycine) transferase $w$ ith a possible route to the formation of the ethanesulfonate derivative of the herbicide together with the structures of metazachlor $\left(\mathrm{R}-\mathrm{CH}_{2}-\mathrm{Cl}\right)$, its ethanesulfonate metabolite $\left(\mathrm{R}-\mathrm{CH}_{2}-\mathrm{SO}_{3}{ }^{-}\right)$, and the major product $\left(\mathrm{R}-\mathrm{CH}_{2}-\mathrm{OH}\right)$ from desulfonation of $\mathrm{R}-\mathrm{CH}_{2}-\mathrm{SO}_{3}{ }^{-}$together with a putative intermediate. Also show $\mathrm{n}$ are the plant safener $\left(\mathrm{R}^{\prime}-\mathrm{CHCl}_{2}\right)$, its ethanesulfonate metabolite $\left(\mathrm{R}^{\prime}-\mathrm{CH}_{2}-\mathrm{SO}_{3}^{-}\right)$, and the putative product $\left(\mathrm{R}^{\prime}-\mathrm{CH}_{2}-\mathrm{OH}\right)$ from desulfonation. A plant safener is a compound added to a pesticide formulation to protect nontarget plants.

prepared, and the enrichments were done with a $30 \mu \mathrm{M}$ sulfur source in phosphate-buffered medium as described previously (9). Enrichment cultures were evaluated after threetransfers, when theturbidity of cultures supplied with $\mathrm{R}-\mathrm{CH}_{2}-\mathrm{SO}_{3}{ }^{-}$was compared with positive ( $30 \mu \mathrm{M}$ sulfate) and negative (no added sulfur source) controls. Where the formation of turbidity was accompanied by the disappearance of $\mathrm{R}-\mathrm{CH}_{2}-\mathrm{SO}_{3}{ }^{-}$, cultures were transferred further. Active cultures were streaked on Plate Count Agar. Picked colonies were inoculated into selective liquid medium where growth and substrate disappearance wereevaluated, and active cultures were restreaked. A culture was considered pure when three successive plates gave identical colonies.

Enrichment cultures $(3 \mathrm{~mL})$ were donein screw-capped 30-mL tubes to prevent contamination from airborne sources of sulfur. Growth yield was measured in sets of 30-mL cultures in 300-mL screw-capped Erlenmeyer flasks. In this case, the sulfur source was present at $0-110 \mu \mathrm{M}$, and the medium ( $\mathrm{pH}$ 7.3) was glycerol, $30 \mathrm{mM}$; Tris base, $50 \mathrm{mM} ; \mathrm{NH}_{4} \mathrm{Cl}, 20 \mathrm{mM} ; \mathrm{MgCl}_{2}, 0.5 \mathrm{mM} ; \mathrm{KCl}, 20 \mathrm{mM}$; $\mathrm{NaCl}$, $20 \mathrm{mM}$; potassium phosphate, $2 \mathrm{mM}$; and trace elements as in Zürrer et al. (9). The growth yield was the slope of the regression linein a graph of protein after theexhaustion of sulfur source vs the initial sulfur concentration; the coefficient of correlation $\left(R^{2}\right)$ was $>0.97$. Growth experiments were done with strain $\mathrm{HLl}$ in the Tris-buffered medium in $500-\mathrm{mL}$ portions in $1-\mathrm{L}$ flasks at $30^{\circ} \mathrm{C}$ with aeration by magnetically driven stirring bars (13). Samples were taken at intervals to determine turbidity $(500 \mathrm{~nm})$, protein, sulfur sources, and products. On occasion, an outgrown culture was washed twice in cold $50 \mathrm{mM}$ potassium phosphate buffer, $\mathrm{pH} 7.2$, and resuspended, 10fold concentrated in phosphate buffer containing $30 \mu \mathrm{M}$
$\mathrm{R}-\mathrm{CH}_{2}-\mathrm{SO}_{3}{ }^{-}$at $30^{\circ} \mathrm{C}$. Samples were taken at intervals to follow the fate of the $\mathrm{R}-\mathrm{CH}_{2}-\mathrm{SO}_{3}{ }^{-}$.

Cultures of strain HL1 were grown to the late log phase, harvested by centifugation, and stored frozen. Cell pellets werethawed, suspended in buffer, and disrupted in a French pressure cell. Whole cells and debris were removed, and glycolate dehydrogenase was examined analogous to the work with the "alcohol dehydrogenase" described elsewhere (14).

\section{Results and Discussion}

$\mathrm{R}-\mathrm{CH}_{2}-\mathrm{SO}_{3}{ }^{-}$was stable in sterile growth medium, indeed the sulfonate was stable to autoclaving in growth medium. Fiveenrichment cultures, one per inoculum, were prepared with $\mathrm{R}-\mathrm{CH}_{2}-\mathrm{SO}_{3}{ }^{-}$as the sole added source of sulfur. Each culture grew and was ranked positive (a) with regard to growth in comparison with positive and negative controls, (b) by partial to complete disappearance of $\mathrm{R}-\mathrm{CH}_{2}-\mathrm{SO}_{3}{ }^{-}$ within 5 days, and (c) by concomitant appearance of a metabolic product. The product was absent from the controls, and its UV spectrum strongly resembled that of $\mathrm{R}-\mathrm{CH}_{2}-\mathrm{SO}_{3}{ }^{-}$(Table 1). Given the range of inocula (see Enrichment Cultures and Growth Conditions), the ability to desulfonate $\mathrm{R}-\mathrm{CH}_{2}-\mathrm{SO}_{3}{ }^{-}$is widespread and is found in areas in which the parent herbicide would scarcely be expected (forest nature reserve and towns).

Thesame putative product from $\mathrm{R}-\mathrm{CH}_{2}-\mathrm{SO}_{3}{ }^{-}$was found in all five mixed cultures. The product was tentatively identified as $\mathrm{R}-\mathrm{CH}_{2}-\mathrm{OH}$ by co-chromatography with authentic material and by identity of the UV spectra of unknown and authentic material (Table 1). Identification of the unknown was confirmed by mass spectrometry (Figure 2). 


\section{TABLE 1}

Chromatographic Behavior of R- $\mathrm{CH}_{2}-\mathrm{SO}_{3}{ }^{-}, \mathrm{R}-\mathrm{CH}_{2}-\mathrm{OH}$, and Related Compounds and Data from Their UV Spectra ${ }^{a}$

\begin{tabular}{lccc} 
& retention & \multicolumn{2}{c}{ date from UV spectra (nm) } \\
\cline { 4 - 5 } \multicolumn{1}{c}{ compound } & time $(\min )$ & max & shoulder \\
$\mathrm{R}-\mathrm{CH}_{2}-\mathrm{SO}_{3}{ }^{-}$ & $3.9 / 4.6$ & 197 & 212 \\
$\mathrm{R}^{-} \mathrm{CH}_{2}-\mathrm{OH}$ & 8.3 & 197 & 213 \\
putative $\mathrm{R}-\mathrm{CH}_{2}-\mathrm{OH}$ & 8.3 & 197 & 212 \\
unknown II & 6.5 & 197 & 212 \\
unknown III & 5.3 & 197 & 212 \\
R-COOH & $3.4 / 3.9$ & 197 & 212
\end{tabular}

${ }^{a} \mathrm{R}-\mathrm{CH}_{2}-\mathrm{SO}_{3}{ }^{-}$and $\mathrm{R}-\mathrm{COOH}$ each form rotamers that are separated by HPLC; the larger peak is italicized. The wavelength for the shoulder in a UV spectrum is considered to be a maximum in the first derivative of the spectrum. The spectra are very similar to one another. The "comparison" facility in the software processing data from the diode array detector detects differences among the spectra. Thus, differences between the spectra of $\mathrm{R}-\mathrm{CH}_{2}-\mathrm{SO}_{3}{ }^{-}$and $\mathrm{R}-\mathrm{CH}_{2}-\mathrm{OH}$ are indicated, whereas the identities of authentic $\mathrm{R}-\mathrm{CH}_{2}-\mathrm{OH}$ and putative $\mathrm{R}-\mathrm{CH}_{2}-\mathrm{OH}$ are supported.

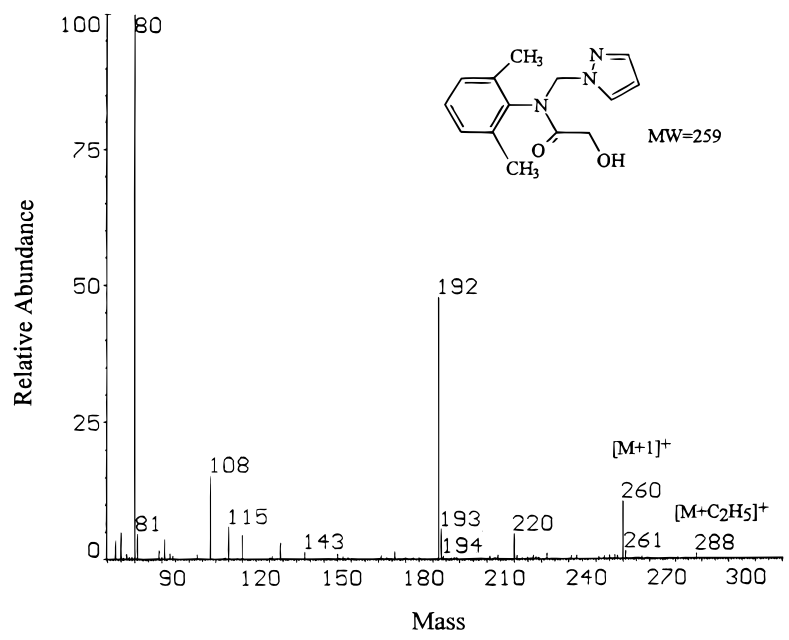

FIGURE 2. Mass spectral identification of putative $\mathrm{R}-\mathrm{CH}_{2}-\mathrm{OH}$. The spectrum was identical with that of authentic material.

Four of the five cultures could be continuously subcultured, and two of these cultures yielded pure cultures, HLI and RK1. The bacterium HL1 was a motile short rod that occurred mainly as single cells or pairs. Strain HL1 wasjudged to be Gram-negative by the L-alanine peptidase reaction and by growth on MacConkey Agar No. 3 and was oxidase-negative. Bacterium RK1 was a motile short rod that occurred singly and in pairs. Strain RK1 was judged to be Gram-negative and was found to beoxidase-positive.

Strain $\mathrm{HL} l$ grew overnight in $30 \mu \mathrm{M} \mathrm{R}-\mathrm{CH}_{2}-\mathrm{SO}_{3}{ }^{-}$medium with $30 \mathrm{mM}$ glycerol as the sole carbon source and inocula of $1 \%(\mathrm{v} / \mathrm{v})$. This organism was examined in more detail. Strain RK1 required 2 days to grow in $30 \mu \mathrm{M} \mathrm{R}-\mathrm{CH}_{2}-\mathrm{SO}_{3}{ }^{-}$ medium with $7 \mathrm{mM}$ succinate as the sole carbon source and an inoculum of $1 \%(\mathrm{v} / \mathrm{v})$. Whereas strain $\mathrm{RK} 1$ retained the ability to utilize R- $\mathrm{CH}_{2}-\mathrm{SO}_{3}{ }^{-}$, it no longer released $\mathrm{R}-\mathrm{CH}_{2-}$ $\mathrm{OH}$ into the medium, as had been observed in the enrichment culture, though traces of an unidentified product were found.

Strain HLl quantitatively removed at least $90 \mu \mathrm{M} \mathrm{R}-\mathrm{CH}_{2-}$ $\mathrm{SO}_{3}{ }^{-}$from the growth medium. The growth yield was 3.0 $\mathrm{kg}$ of protein/mol of sulfonate compared with $2.9 \mathrm{~kg}$ of protein/mol of sulfate, a normal value $(10,15)$. The growth yield data from strain RK1 essentially resembled those of

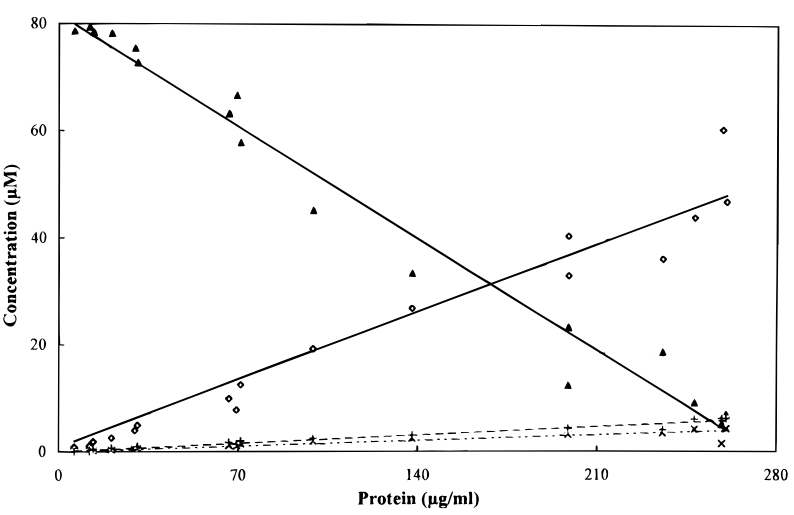

FIGURE 3. Differential grow th curve of strain HL1 utilizing $\mathrm{R}-\mathrm{CH}_{2}$ $\mathrm{SO}_{3}{ }^{-}$as the sole added source of sulfur. The organism was subcultured from $80 \mu \mathrm{M} \mathrm{R}-\mathrm{CH}_{2}-\mathrm{SO}_{3}{ }^{-}$and $30 \mathrm{mM}$ glycerol salts medium into homologous medium, and samples were taken at intervals for the determination of protein, sulfur source, and metabolic products. Substrate utilization and product formation are plotted as a function of growth. This curve is an exception in that the $\mathrm{R}-\mathrm{CH}_{2}-\mathrm{SO}_{3}{ }^{-}$was not fully utilized. The jump in the concentration of $\mathrm{R}-\mathrm{CH}_{2}-\mathrm{OH}$ after the end of grow th is represented by the highest value in the line. $\mathrm{R}-\mathrm{CH}_{2}-\mathrm{SO}_{3}{ }^{-}, \triangle$; $\mathrm{R}-\mathrm{CH}_{2}-\mathrm{OH}, \diamond$; unknow n II, $\times$; unknow n III, + .

strain HL1. We thus have a mass balance for the sulfono moiety, which is recovered in protein.

Theyield of the carbon skeleton of $\mathrm{R}-\mathrm{CH}_{2}-\mathrm{SO}_{3}{ }^{-}$as $\mathrm{R}-\mathrm{CH}_{2-}$ $\mathrm{OH}$ was usually in the range $60-90 \%$ (strain HL1), whereby the higher yield was at the higher sulfonate concentrations $(90 \mu \mathrm{M})$. R- $\mathrm{CH}_{2}-\mathrm{OH}$ was not lost during centrifugation and filtration of authentic material, and we do not know the fate of the missing material. It is clear, however, that a major portion of the R- $\mathrm{CH}_{2}-\mathrm{SO}_{3}-$ molecule is acounted for.

Occasionally, strain $\mathrm{HL} 1$ yielded about half the expected concentration of $\mathrm{R}-\mathrm{CH}_{2}-\mathrm{OH}$ together with another product (II, in a single peak) with a similar UV spectrum to $\mathrm{R}^{-} \mathrm{CH}_{2-}$ $\mathrm{OH}$, but with a shorter retention time (Table 1). Assuming similar molar extinction coefficients for these two compounds, product II represented $<10 \%$ of theinitial sulfonate. Strain RK1 released no obvious desulfonation product. We presume $\mathrm{R}-\mathrm{CH}_{2}-\mathrm{OH}$ to be subject to further metabolic transformations, for which conditions have not been optimized.

The specific growth rate $(\mu)$ of strain HL1 was $0.32 \mathrm{~h}^{-1}$ with $\mathrm{R}-\mathrm{CH}_{2}-\mathrm{SO}_{3}{ }^{-}$or $0.50 \mathrm{~h}^{-1}$ with sulfate, which indicates sulfur assimilation into the cell between $30 \mu \mathrm{kat} / \mathrm{kg}$ of protein ( $\mathrm{R}-\mathrm{CH}_{2}-\mathrm{SO}_{3}{ }^{-}$) and $49 \mu \mathrm{kat} / \mathrm{kg}$ of protein (sulfate). When followed kinetically, the first product detected from $\mathrm{R}-\mathrm{CH}_{2}-\mathrm{SO}_{3}{ }^{-}$was product II. Both product II and $\mathrm{R}-\mathrm{CH}_{2-}$ $\mathrm{OH}$ were present simultaneously during growth. Thereafter, the concentration of product II essentially disappeared (Figure 3). Yet another product (III) was detected, which we have not identified. Product III sometimes appeared late in the growth curve and sometimes at the start of the experiment (Figure 3). After the end of growth, the level of $\mathrm{R}-\mathrm{CH}_{2}-\mathrm{OH}$ rose overnight (Figure 3).

We were unable to detect desulfonation in cell suspensions or in cell extracts. The known hydrolytic desulfonation, that of taurine, yields a methyl group subsequent to a rearrangement reaction $(16,17)$, whereas we observe the glycolate. We thus hypothesized that desulfonation of $\mathrm{R}-\mathrm{CH}_{2}-\mathrm{SO}_{3}{ }^{-}$would lead to the formation of the glyoxylate (R-CHO) (cf. refs 18 and 19), on the assumption that an oxygenase was involved. We have as yet found no alcohol dehydrogenase in strain HL1, which could interconvert "glycolate" and "glyoxylate", so the reactionsleading to the 
formation of $\mathrm{R}-\mathrm{CH}_{2}-\mathrm{OH}$ are still undefined. The glycolate was not a substrate for horse liver alcohol dehydrogenase.

The substrate range of strain HL1 for compoundssimilar to $\mathrm{R}-\mathrm{CH}_{2}-\mathrm{SO}_{3}{ }^{-}$(cf. Introduction) could not betested because so few ethanesulfonates were made available to us. One alternative substrate wastested (Figure 1), and it supported growth concomitant with substrate (retention time $3.6 \mathrm{~min}$ ) disappearance and the formation of a putative product (retention time $6.8 \mathrm{~min}$ ), which we did not identify. The organism grew with ethylsulfonate or pentylsulfonate but not with taurine as the sole added source of sulfur.

The relevance of a degradative enzyme is not limited to its activity, it also involves its regulation. Recognition of the regulation of metabolism of organosulfonates is not new (20-22), but we now conclude that a global regulatory network is involved (sulfate starvation-induced stimulon, SSIS) $(8,23)$, and this has yet to be evaluated as an ecological phenomenon. The potential ecological relevance of the network should be considered together with the growing awareness of the extent of pollution by sulfonated compounds (e.g. refs 6 and 24-27) and with a realization that the range of naturally occurring sulfonates has widened vastly from a few, largely aliphatic compounds (28) to humus (29). Theturnover of humus, regardless of how slow, must yield myriad aromatic, and presumablyaliphatic, sulfonates. In this light, the widespread desulfonation of xenobiotic sulfonates in this work and elsewhere $(9,10)$ is surely not surprizing but is a reflection of the previously unrecognized requirement for desulfonation in the cycling of humus in soil and humic materials in water.

We thus presume that the desulfonation of $\mathrm{R}-\mathrm{CH}_{2}-\mathrm{SO}_{3}{ }^{-}$ is catalyzed by enzymes whose synthesis is regulated by the SSIS. In the laboratory, the desulfonative enzymes in this network are expressed in the absence of sulfate (23). There is one example of the expression in nature of genes, which we presume to be regulated by a sulfate starvationinduced stimulon (8), the adaptive eradication of methionine and cysteine from bacterial light-harvesting proteins in the presence of low sulfate concentrations (30). The expression of SSIScan be expected in soil, wheremost sulfur is present in organic form and free sulfate is rare (e.g., refs 31-33), as discussed by Kertesz et al. (8). One must distinguish, however, among soil usage and the concentration of free sulfate, which can obviously vary from several hundred micromolars $(\mu \mathrm{M})$ and effectively zero (e.g., ref 34). So a desulfonation may be expected in a forest soil, but not in an agricultural soil. Proof of expression of SSIS is not yet available under any condition, because suitable genetic tools are only now approaching development (cf. ref 35).

\section{Acknowledgments}

H.L. was supported by funds supplied by the Universität Konstanz. We thank Don Griffen for providing the direct probemassspectrometry data. R. Kiewitz, G. Fritz, F. Zeller, and $\mathrm{G}$. Keller did enrichment cultures. We are grateful to BASF for providing R- $\mathrm{CH}_{2}-\mathrm{SO}_{3}{ }^{-}(\mathrm{BH} 479-8), \mathrm{R}-\mathrm{CH}_{2}-\mathrm{OH}(\mathrm{BH}$ 479-1), $\mathrm{R}-\mathrm{COOH}$ (BH 479-4), and $\mathrm{R}^{\prime}-\mathrm{CH}_{2}-\mathrm{SO}_{3}{ }^{-}$.

\section{Literature Cited}

(1) Sharp, D. B. In Herbicides: Chemistry, Degradation and Mode of Action; Kearney, P. C., Kaufman, D. D., Eds.; Marcel Dekker: New York, 1988; Vol. III, pp 301-333.

(2) Lamoureux, G. L.; Rusness, D. G. Pestic. Biochem. Physiol. 1989, 34, 187.

(3) Feng, P. C. C. Pestic. Biochem. Physiol. 1991, 40, 136.

(4) Macomber, C.; Bushway, R. J.; Perkins, L. B.; Baker, D.; Fan, T. S.; Ferguson, B. S. J. Agric. Food Chem. 1993, 40, 1450.

(5) Keller, E.; Dreher, W. In Proceedings of the Eighth International Conference of Pesticide Chemistry; Washington, D.C., 1994; p 180.

(6) Field, J. A.; Thurman, E. M. Environ. Sci. Technol., submitted for publication.

(7) Cook, A. M.; Grossenbacher, H.; Hütter, R. Experientia 1983, 39 , 1191.

(8) Kertesz, M. A.; Cook, A. M.; Leisinger, T. FEMS Microbiol. Rev. 1994, 15, 195.

(9) Zürrer, D.; Cook, A. M.; Leisinger, T. Appl. Environ. Microbiol. 1987, 53, 1459.

(10) Kertesz, M. A.; Kölbener, P.; Stockinger, H.; Beil, S.; Cook, A. M. Appl. Environ. Microbiol. 1994, 60, 2296.

(11) Cook, A. M.; Hütter, R. J. Agric. Food Chem. 1981, 29, 1135.

(12) Kölbener, P.; Baumann, U.; Cook, A. M.; Leisinger, T. Water Res. 1994, 28, 1855.

(13) Harvey, N. L.; Fewson, C. A.; Holms, W. H. Lab. Pract. 1968, 17, 1134.

(14) Locher, H. H.; Malli, C.; Hooper, S.; Vorherr, T.; Leisinger, T. Cook, A. M. J. Gen. Microbiol. 1991, 137, 2201.

(15) Cook, A. M. FEMS Microbiol. Rev. 1987, 46, 93

(16) Kondo, H.; Ishimoto, M. J. Biochem. 1975, 78, 317.

(17) Shimamoto, G.; Berk, R. S. Biochim. Biophys. Acta 1980, 632, 121.

(18) Thysse, G. J. E.; Wanders, T. H. Antonievan Leeuwenhoek 1974, 40, 25.

(19) Quick, A.; Russell, N. J.; Hales, S. G.; White, G. F. Microbiology (Reading U.K.) 1994, 140, 2991.

(20) Roberts, R. B.; Abelson, P. H.; Cowie, D. B.; Bolton, E. T.; Britten, R. J.Studies of Biosynthesisin Escherichia coli; Carnegielnstitute of Washington: Washington, DC, 1955; pp 318-405.

(21) Seitz, A. P.; Leadbetter, E. R.; Godchaux, W., III. Arch. Microbiol. 1993, 159, 440.

(22) Uria-Nickelsen, M. R.; Leadbetter, E. R.; Godchaux, W., III. J. Gen. Microbiol. 1993, 139, 203.

(23) Kertesz, M. A.; Leisinger, T.; Cook, A. M. J. Bacteriol. 1993, 175, 1187.

(24) Thurman, E. M.; Willoughby, T.; Barber, L. B.; Thorn, K. A. Anal. Chem. 1987, 59, 1798.

(25) Kim, I. S.; Sasinos, F. I.; Stephens, R. D.; Brown, M. A. Environ. Sci. Technol. 1990, 24, 1832.

(26) Lange, F. T.; Wenz, M.; Brauch, H.-J.J. High Resolut. Chromatogr. 1995, 18, 243.

(27) Field, J. A.; Barber, L. B.; Thurman, E. M.; Moore, B. L.; Lawrence D. L.; Peake, D. A. Environ. Sci. Technol. 1992, 26, 1140.

(28) Cook, A. M.; Leisinger, T. In Environmental Biotechnology, Vol. 1; Verachtert, H., Verstraete, W., Eds.; Koninklijke Vlaamse Ingenieursvebeiniging: Antwerpen, 1991; pp 115-121.

(29) van Loon, W. M. G. M.; Boon, J. J.; de Groot, B. Environ. Sci. Technol. 1993, 27, 2387.

(30) Mazel, D.; Marliére, P. Nature (London) 1989, 341, 245.

(31) Autry, A. R.; Fitzgerald, J. W. Biol. Fertil. Soils 1990, 10, 50.

(32) Fitzgerald, J. W. In Sulfur in the Environment, Part II; Nriagu, J. O., Ed.; Wiley: New York, 1978; pp 391-443.

(33) Killham, K. Soil Ecology; CambridgeUniversity Press: Cambridge, 1994.

(34) Ward, D. M.; Winfrey, M. R. Adv. Aquat. Microbiol. 1985, 3, 141.

(35) Beil, S.; Kehrli, H.; James, P.; Staudenmann, W.; Cook, A. M.; Leisinger, T.; Kertesz, M. A. Eur. J. Biochem. 1995, 229, 385. 